\title{
SIMULATION OF GROUND-WATER FLOW IN THE ANTLERS AQUIFER IN SOUTHEASTERN OKLAHOMA AND NORTHEASTERN TEXAS
}

\section{BY ROBERT B. MORTON}

Prepared in cooperation with the

U.S. Army Corps of Engineers

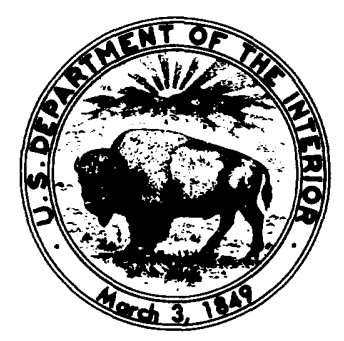

U.S. GEOLOGICAL SURVEY

WATER-RESOURCES INVESTIGATIONS REPORT 88-4208

Oklahoma City, Oklahoma 1992 


\title{
U.S. DEPARTMENT OF THE INTERIOR
}

\author{
MANUEL LUJAN, Jr., Secretary
}

\author{
U.S. GEOLOGICAL SURVEY \\ DALLAS L. PECK, Director
}

For additional information write to:

District Chief

U.S. Geological Survey

202 NW 66th Street, Bldg. 7

Oklahoma City, Oklahoma 73116
Copies of this report can

be purchased from:

U.S. Geological Survey

Books and Open-File Reports Section

Federal Center

Box 25425

Denver, Colorado 80225 


\section{ERRATA:}

Plates 1-7 are incorrectly labeled as:

OPEN-FILE REPORT 88-4208;

they should be labeled as:

WATER-RESOURCES INVESTIGATIONS

REPORT 88-4208. 


\section{CONTENTS}

$\begin{array}{ll}\text { Abstract } 1 & \\ \text { Introduction } 1\end{array}$

Purpose and scope 2

Location and general description of the study area 2

Previous studies 2

Acknowledgments 4

Geologic setting 4

Ground-water hydrology of the study area 5

Ground-water flow system 5

Recharge and discharge 6

Hydraulic conductivity, storage coefficient, and specific yield 7

Ground-water use 8

Description of the digital model 9

General discussion 9

Model boundaries 10

Assumptions and calibration of the model 11

Sensitivity analysis 14

Pumping simulations for decennial years, 1990-2040 14

Summary and conclusions 18

Selected references 18

Glossary of technical terms 20

\section{PLATES}

[Plates are in pocket at back of report.]

1. Maps showing:
A. Observed potentiometric surface, 1970, Antlers aquifer
B. Altitude of the top of the Antlers aquifer
C. Altitude of the base of the Antlers aquifer

2. Maps showing:
A. Saturated thickness, 1970, Antlers aquifer
B. Observed potentiometric surface, 1970 , in confining unit overlying the Antlers aquifer
C. Finite-difference grid and locations of boundaries used for modeled area 
3. Maps showing:

A. Computed potentiometric surface for the steady-state simulation of 1970 head distribution, Antlers aquifer

B. Potentiometric surface in the Antlers aquifer, 1990

C. Potentiometric surface in the Antlers aquifer, 2000

4. Maps showing:
A. Potentiometric surface in the Antlers aquifer, 2010
B. Potentiometric surface in the Antlers aquifer, 2020,
C. Potentiometric surface in the Antlers aquifer, 2030

5. Maps showing:
A. Potentiometric surface in the Antlers aquifer, 2040
B. Drawdown in the Antlers aquifer, 1990
C. Drawdown in the Antlers aquifer, 2000

6. Maps showing:
A. Drawdown in the Antlers aquifer, 2010
B. Drawdown in the Antlers aquifer, 2020
C. Drawdown in the Antlers aquifer, 2030

7. Maps showing:

A. Drawdown in the Antlers aquifer, 2040

B. Projected saturated thickness, Antlers aquifer, 2040

C. Potential well yield, Antlers aquifer

\section{FIGURES}

1. Map showing location of study area 3

2. Water-level hydrograph of well in Antlers aquifer for calendar years 1956-84 6

3. Diagrammatic sketch showing flow components from the steady-state mass balance 13

4. Graphs showing sensitivity to change in hydraulic conductivity of confining unit, aquifer hydraulic conductivity, and recharge rate during steady-state simulation of 1970 head distribution 16

\section{TABLES}

1. Steady-state mass balance for $1970 \quad 13$

2. Mass balance for transient simulation (1911-70) 14

3. Pumping rates for 1980 in excess of 35 million gallons per year per grid cell from municipal, industrial, and irrigation wells in southeastern Oklahoma and northeastern Texas, and projected decennial pumping rates to $2040 \quad 15$

4. Mass balance at end of projected simulation to 2040 


\begin{tabular}{|c|c|c|}
\hline Multiply & By & To obtain \\
\hline acre & 4.047 & square kilometer \\
\hline acre-foot (acre-ft) & 1,233 & cubic meter \\
\hline $\begin{array}{l}\text { acre-foot per year } \\
(\text { acre-ft/yr) }\end{array}$ & 0.00003911 & cubic meter per second \\
\hline foot $(\mathrm{ft})$ & 0.3048 & meter \\
\hline cubic foot $\left(\mathrm{ft}^{3}\right)$ & 0.02832 & cubic meter \\
\hline $\begin{array}{l}\text { cubic foot per second } \\
\left(\mathrm{ft}^{3} / \mathrm{s}\right)\end{array}$ & 0.02832 & cubic meter per second \\
\hline foot per day $(\mathrm{ft} / \mathrm{d})$ & 0.000003527 & meter per second \\
\hline $\begin{array}{l}\text { foot squared per day } \\
\left(\mathrm{ft}^{2} / \mathrm{d}\right)\end{array}$ & 0.000001075 & square meter per second \\
\hline foot per mile $(\mathrm{ft} / \mathrm{mi})$ & 0.1894 & meter per kilometer \\
\hline gallon (gal) & 3.785 & liter \\
\hline gallon per minute $(\mathrm{gal} / \mathrm{min})$ & 0.06309 & liter per second \\
\hline $\begin{array}{l}\text { gallon per minute per foot } \\
{[(\mathrm{gal} / \mathrm{min}) / \mathrm{ft}]}\end{array}$ & 0.2070 & liter per second per meter \\
\hline gallon per day (gal/d) & 0.0000438 & liter per second \\
\hline $\begin{array}{l}\text { million gallons per year } \\
(\mathrm{Mgal} / \mathrm{yr})\end{array}$ & 0.1200 & liter per second \\
\hline inch (in.) & 25.4 & millimeter \\
\hline inch per year (in/yr) & 0.0000008054 & millimeter per second \\
\hline inch per acre (in/acre) & 6.2756 & millimeter per square kilometer \\
\hline mile $(\mathrm{mi})$ & 1.609 & kilometer \\
\hline square mile $\left(\mathrm{mi}^{2}\right)$ & 2.590 & square kilometer \\
\hline
\end{tabular}




\title{
SIMULATION OF GROUND-WATER FLOW IN THE ANTLERS AQUIFER IN SOUTHEASTERN OKLAHOMA AND NORTHEASTERN TEXAS
}

\author{
By Robert B. Morton
}

\section{ABSTRACT}

The Antlers Sandstone of Early Cretaceous age occurs in all or parts of Atoka, Bryan, Carter, Choctaw, Johnston, Love, Marshall, McCurtain, and Pushmataha Counties, a 4,400-square-mile area in southeastern Oklahoma parallel to the Red River. The sandstone comprising the Antlers aquifer is exposed in the northern one-third of the area, and ground water in the outcrop area is unconfined.

Younger Cretaceous rocks overlie the Antlers in the southern two-thirds of the study area where the aquifer is confined. The Antlers extends in the subsurface south into Texas where it underlies all or parts of Bowie, Cooke, Fannin, Grayson, Lamar, and Red River Counties. An area of approximately 5,400 square miles in Texas is included in the study.

The Antlers Sandstone consists of sand, clay, conglomerate, and limestone deposited on an erosional surface of Paleozoic rocks. Saturated thickness in the Antlers ranges from 0 feet at the updip limit to probably more than 2,000 feet, 25 to 30 miles south of the Red River.

Simulated recharge to the Antlers based on model calibration ranges from 0.32 to about 0.96 inch per year. Base flow increases where streams cross the Antlers outcrop, indicating that the aquifer supplies much of the base flow.

Pumpage rates for 1980 in excess of 35 million gallons per year per grid cell for public supply, irrigation, and industrial uses total 872 million gallons in the Oklahoma part of the Antlers and 5,228 million gallons in the Texas part of the Antlers.

Ground-water flow in the Antlers aquifer was simulated using one active layer in a three-dimensional finite-difference mathematical model. Simulated aquifer hydraulic conductivity values range from 0.87 to 3.75 feet per day. A vertical hydraulic conductivity of $1.5 \times 10^{-4}$ foot per day was specified for the younger confining unit at the start of the simulation. An average storage coefficient of 0.0005 was specified for the confined part of the aquifer; a specific yield of 0.17 was specified for the unconfined part.

Because pumping from the Antlers is minimal, calibration under transient conditions was not possible. Consequently, the head changes resulting from projection simulations in this study are estimates only. Volumetric results of the six projection simulations from the years 1990 to 2040 indicate that the decrease in the volume of ground water in storage due to pumping approximately $9,700,000$ acre-feet from 1970 to 2040 is less than 0.1 percent.

\section{INTRODUCTION}

The Antlers Sandstone comprises the Antlers aquifer and is one of the major aquifers in Oklahoma and adjoining parts of Texas.

Although current use of the Antlers in Oklahoma is minimal, several municipalities in northeastern Texas depend on the Antlers for 
water supply. Although no water-quality or supply problems concerning the Antlers now (1986) exist, increased use of the aquifer may alter the current situation.

\section{Purpose and Scope}

This report presents the results of a study by the U.S. Geological Survey in cooperation with the U.S. Army Corps of Engineers to determine the hydrologic effects of increased pumpage to the year 2040 on the potentiometric surface, saturated thickness, drawdown, and potential well yield for the Antlers.

An additional purpose of the study is to obtain an improved understanding of the aquifer hydraulic conductivity, storage, recharge, the flow system within the aquifer, and the vertical conductivity of the younger confining unit. Digital model simulations provide a reasonable method of helping to achieve this understanding.

Data from previous studies were used to simulate ground-water flow in the Antlers aquifer by using a finite-difference numerical model with three-dimensional capability. For the purpose of this study, however, a twodimensional simulation was used. Simulations of the possible effects of increased pumpage were made for the decennial years, 1990 2040.

\section{Location and General Description of the Study Area}

The study area includes all or parts of Atoka, Bryan, Carter, Choctaw, Johnston, Love, Marshall, McCurtain, and Pushmataha Counties along the Red River in southeastern Oklahoma; and Bowie, Cooke, Fannin, Grayson, Lamar, and Red River Counties in Texas (fig. 1). The area underlain by the aquifer in Oklahoma is about $4,400 \mathrm{mi}^{2}$ and extends from T. 2 S. to T. 10 S., a distance of about $50 \mathrm{mi}$; and from R. 3 W. to R. 27 E., a distance of about $175 \mathrm{mi}$. The area underlain by the Ant- lers within the study area in Texas is approximately $5,400 \mathrm{mi}^{2}$.

The study area is included in the West Gulf Coastal Plain section of the Coastal Plain physiographic province (Fenneman and Johnson, 1946). The mean annual temperature $(1941-70)$ is about $64^{\circ} \mathrm{F}\left(18^{\circ} \mathrm{C}\right)$ (U.S. Department of Commerce, 1973), and the mean annual precipitation ranges from about 34 in. in the western part of the study area to $50 \mathrm{in}$. in the east. The wettest months are April, May, and June followed by September and October (Hart and Davis, 1981). Most of the land surface is a south-southeast sloping plain broken by several north-northwest facing low escarpments caused by erosion of generally southward-dipping beds of limestone. Additional breaks in the plain are caused by tributaries to the Red River, the principal stream. The major tributaries in Oklahoma are Blue River, Kiamichi River, Little River, Clear Boggy Creek, and Muddy Boggy Creek (plate 1A), and the Washita River, all of which have some flow most of the year. The altitude of the land surface generally is between 400 and 1,000 feet and local relief is approximately 100 feet.

\section{Previous Studies}

Several studies have been made of the geology and mineral resources in the study area. Davis (1960) described the geology and ground-water resources of southern McCurtain County. Frederickson, Redman, and Westheimer (1965) described the geology and petroleum operations in Love County. Hart (1974) published a reconnaissance atlas of water availability and water quality that included approximately the western half of the study area. Huffman and others (1975) reported on the geology and mineral resources in Choctaw County. Huffman and others (1978) reported on the geology and mineral resources of Bryan County. The geohydrology of the Antlers aquifer was described by Hart and Davis (1981) and some of the aquifer characteristics 


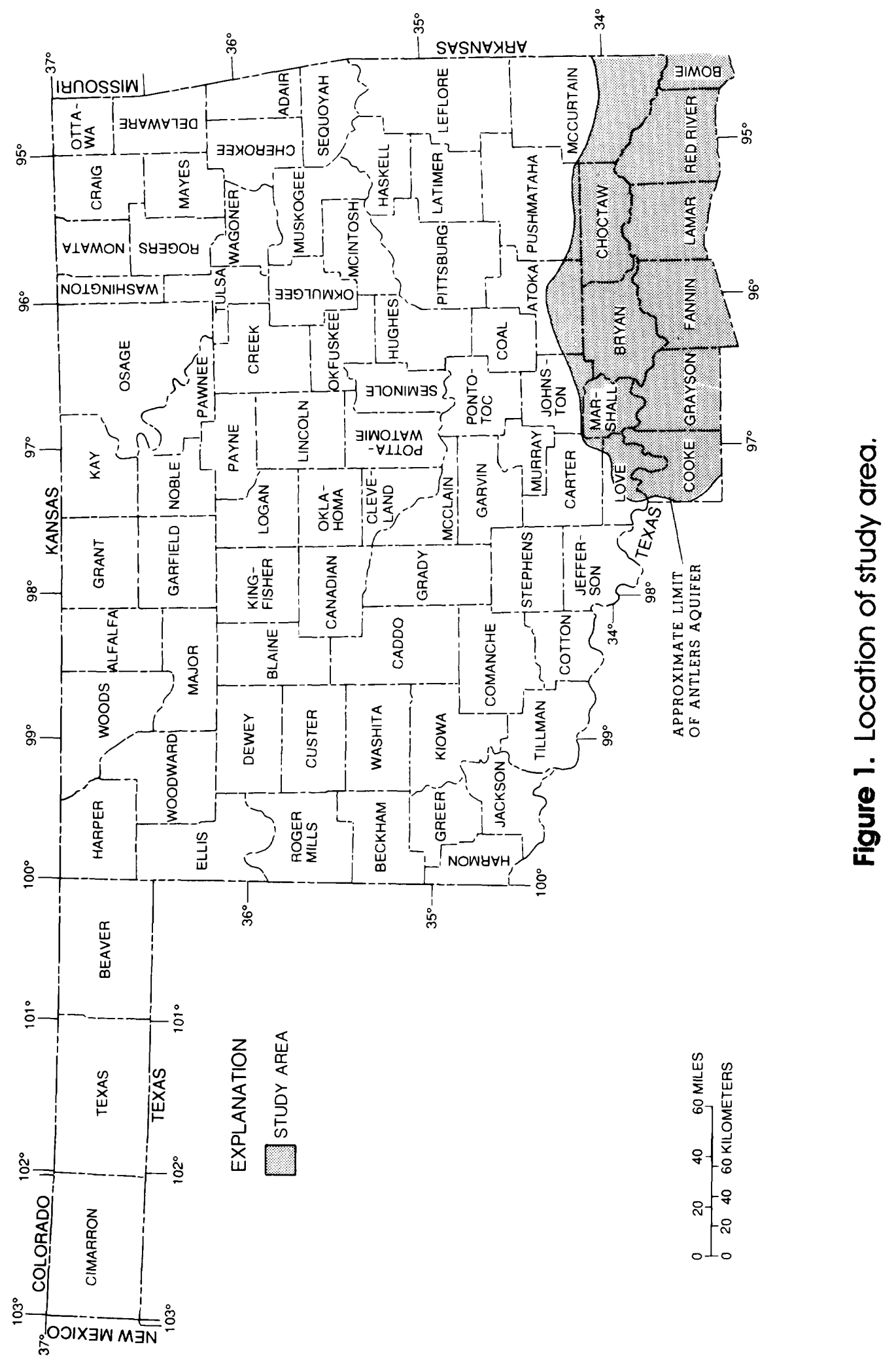


developed by Hart and Davis have been used in the current study. More recently, Marcher and Bergman (1983) completed a reconnaissance atlas of water availability and water quality covering the eastern part of the study area.

Additional reports covering the geology and ground-water resources of the study area are listed in the selected references. Of particular interest is the work of Nordstrom (1982) describing the occurrence, availability, and chemical quality of ground water in Cretaceous aquifers of north-central Texas.

\section{Acknowledgments}

Personnel of the Oklahoma Water Resources Board staff made water-use data available, and the author is most grateful for their cooperation. Gratitude also is extended to many water users in the study area who supplied requested water-use data. A special thanks is due the personnel of the Texas Department of Water Resources and especially P.L. Nordstrom who generously provided the geohydrologic information used for the Texas part of the modeled area.

\section{GEOLOGIC SETTING}

The following geologic description of the Antlers Sandstone is modified from Hart and Davis (1981). The Antlers Sandstone is a Lower Cretaceous transgressive marine rock unit that is progressively younger northward and is the basal Cretaceous formation in southeastern Oklahoma, except in McCurtain County where it is underlain by the De Queen Limestone and the Holly Creek Formation of Early Cretaceous age. The relation of the Antlers Sandstone to other Lower Cretaceous rock units has been the subject of much debate over the years. The Oklahoma Geological Survey recognizes the Antlers Sandstone in Oklahoma as used in this report. The U.S. Geological Survey recognizes the equivalent Paluxy Formation of the Trinity Group in Oklahoma as recognized in Texas (Huffman and others, 1978). In the outcrop (plate 1A) the Antlers consists of sand, clay, conglomerate, and limestone deposited in a marine environment over an erosional surface of Paleozoic rocks, which are mostly shale, siltstone, and sandstone. In most areas, the basal unit of the Antlers is composed of clay- and silt-size material. Locally, the basal unit consists of conglomerate or calcareous sandstone. The upper part of the Antlers consists of beds of sand, poorly cemented sandstone, sandy shale, silt, and clay; crossbedded sand is common. The color of the Antlers ranges from white to yellow and maroon, but red and yellow shades predominate.

As shown on the plates, the Antlers Sandstone is exposed in an east-west belt ranging in width from 3 to $15 \mathrm{mi}$. The dip generally is south, and the amount of dip on the top of the Antlers (plate 1B) ranges from about $35 \mathrm{ft} / \mathrm{mi}$ on the east to about $90 \mathrm{ft} / \mathrm{mi}$ on the west and averages about $60 \mathrm{ft} / \mathrm{mi}$. The dip on the base of the Antlers (plate 1C) ranges from about 35 $\mathrm{ft} / \mathrm{mi}$ on the east to about $105 \mathrm{ft} / \mathrm{mi}$ on the west and averages about $75 \mathrm{ft} / \mathrm{mi}$. Altitudes of the top and base of the Antlers were determined from geophysical logs of about 230 oil and gas test wells.

South of the outcrop area the Antlers is overlain by younger Cretaceous rocks of the Comanchean and Gulfian Series, which act as a confining unit above the Antlers. The Goodland Limestone immediately overlies the Antlers Sandstone in Oklahoma according to Davis (1960). The Goodland Limestone is described as a hard, white, often massive bedded, finely crystalline, relatively pure, fossiliferous limestone that in places caps northfacing escarpments. The limestone is about 25 $\mathrm{ft}$ thick over much of the area, but thickens to $55 \mathrm{ft}$ in Choctaw County and to $95 \mathrm{ft}$ in southeastern McCurtain County. The rocks above the Goodland consist mostly of interbedded limestone and shale; however, 35 to $45 \mathrm{ft}$ of 
sandstone also is present, and as much as $435 \mathrm{ft}$ of sandstone occurs in the Woodbine Formation, which is exposed over much of the southern half of Bryan and Choctaw Counties, Oklahoma, and in parts of Cooke, Grayson, Fannin, Lamar, and Red River Counties, Texas.

\section{GROUND-WATER HYDROLOGY OF THE STUDY AREA}

\section{Ground-Water Flow System}

The Antlers aquifer is equivalent in all respects to the Antlers Sandstone described in the section on geology. Water in the Antlers is unconfined in the outcrop, but is confined where overlain by younger rocks. Observed saturated thickness of the Antlers aquifer ranges from 0 at the updip limit probably to more than $2,000 \mathrm{ft}, 25$ to $30 \mathrm{mi}$ south of the Red River (plate 2A). The saturated thickness of the younger confining rocks ranges from 0 at the updip limit to approximately $3,000 \mathrm{ft}, 25$ to $30 \mathrm{mi}$ south of the Red River.

Plate 1A shows that the potentiometric surface in the Antlers slopes generally to the south-southeast except along such streams as Blue River and Clear Boggy and Muddy Boggy Creeks where the gradient is toward the streams. Water is assumed to move at right angles to the potentiometric contours and in the direction of lower head (plate 1A). Thus, the general movement of water in the Antlers, and in the younger confining unit (plate 2B) is to the south-southeast but locally is interrupted by flow toward the streams. Data used in the preparation of plate 2B were taken from Havens and Bergman (1976).

Because the potentiometric contours in the Antlers show flow toward several of the tributary streams in the confined part of the Antlers, the conclusion follows that there is leakage between the Antlers and the younger confining unit. Confinement by the younger confining unit is imperfect because the vertical hydraulic conductivity of the confining unit is sufficient to allow water to move upward or downward between the Antlers and the younger confining unit in some places. Contour lines on plates $1 \mathrm{~A}$ and $2 \mathrm{~B}$ show that the head in the Antlers is as high or higher than the head in the younger confining unit in places. The head in the Antlers is higher than the head in the younger confining unit at the following locations: Along Red River downstream from T. 8 S., R. 7 E.; along Blue River downstream from T. 6 S., R. 10 E.; along Boggy Creek downstream from T. 6 S., R. 15 E.; along Kiamichi River downstream from T. 6 S., R. 18 E.; and along Little River in T. 6 S., R. 22 E. and T. 7 S., Rs. 23 and 24 E. Several wells completed in the Antlers aquifer are flowing wells in the areas cited above, thereby providing further evidence of locally higher head in the Antlers. Additional control points and a smaller contour interval would better define the areas of higher head in the Antlers. Other than in the areas cited above, however, the head in the Antlers usually is lower than the head in the younger confining unit.

In more extreme downdip areas, the regional flow system probably includes considerable upward leakage of water from the Antlers into the younger confining unit. Plate $1 \mathrm{~A}$ shows the approximate position of the downdip limit of fresh to slightly saline water $(1,000$ to 3,000 milligrams per liter dissolved solids) according to Nordstrom (1982). South of this interface dissolved-solids concentrations in the Antlers aquifer exceed 3,000 mg/ $\mathrm{L}$; therefore, continued movement of water downgradient probably decreases.

Water-level hydrographs are useful for illustrating long-term trends in head at specific locations within an aquifer system. No continuous long-term ground-water-level data from which hydrographs could be prepared are available for the Antlers aquifer in the study area. However, a long-term hydrograph, for 


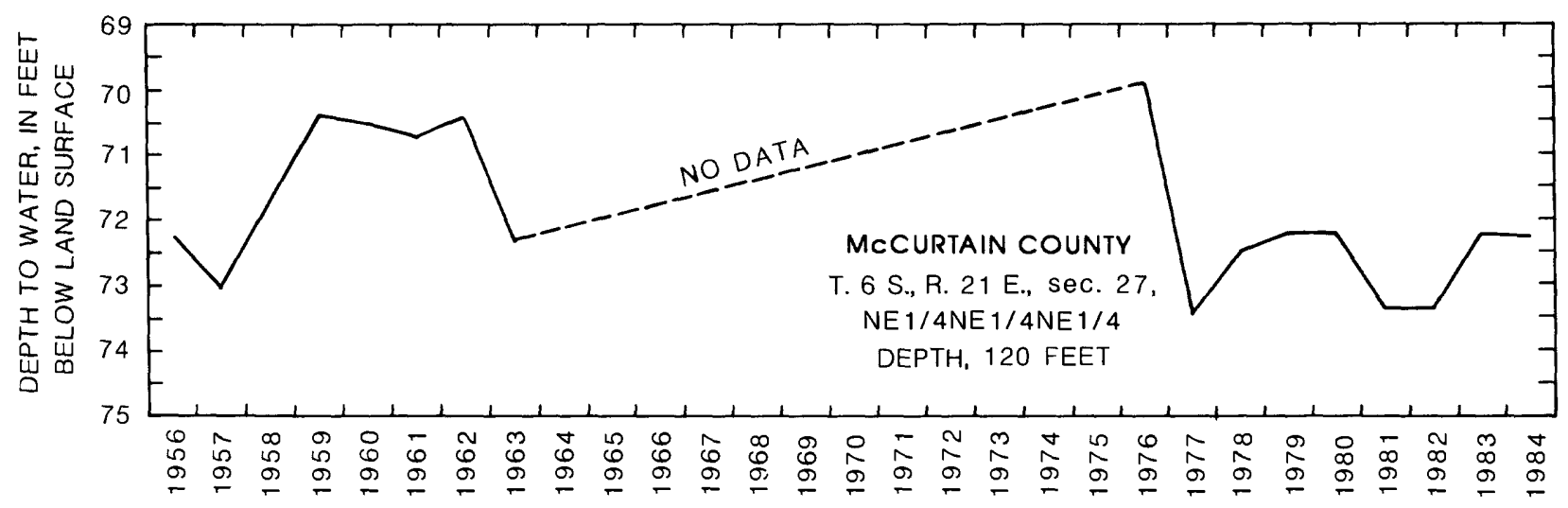

Figure 2. Water-level hydrograph of well in Antlers aquifer for calendar years 1956-84.

the years 1956-84 with no data for 13 years, is shown in figure 2. Although water-level changes of several feet have occurred for relatively short intervals over the years, the hydrograph shows that, over the long term, there has been no significant change in the water level in the McCurtain County well from 1956 to 1984.

The estimated small volume of water currently (1986) being pumped $(6,700 \mathrm{Mgal} / \mathrm{yr})$, and the absence of long-term water-level changes in the McCurtain County well, suggest that the Antlers is close to a steady-state condition. Unfortunately, no long-term baseflow data are available to give additional support to this assumption.

\section{Recharge and Discharge}

Recharge can be estimated from winter stream discharge. During the winter, evapotranspiration is greatly reduced, irrigation pumpage usually is at a minimum, and precipitation is small. Consequently, most streamflow in the winter is from ground-water discharge. If the aquifer is at steady state, recharge approximates discharge, and because the streams do not originate in the outcrop, the increased streamflow across the aquifer outcrop is an estimate of recharge. However, the recharge value thus determined may be some- what less than the total recharge. Where both unconfined and confined conditions exist, part of the recharge may not discharge into streams on the outcrop but may continue downgradient beneath the younger confining unit.

Locally, the amount of recharge is partly a function of soil types; loose, sandy, and loamy soils generally increase the potential for recharge, whereas tight, clayey soils reduce the potential for recharge. Surface soil over much of the Antlers outcrop is a loamy soil (U.S. Department of Agriculture, 1966, 1974, 1977, 1978, 1979a, b, c, d, 1980).

Hart and Davis (1981) made streamflow measurements during the winter of 1975-76 on Little Hauani, Dumpling, Davis, and Gates Creeks (plate 2A), which are widely spaced across the Antlers outcrop. If the streamflow gain measured in the stated creeks in the winter of 1975-76 is assumed to provide an estimate of recharge over a wide expanse of the Antlers aquifer, then such recharge is estimated to range from 0.76 to $3 \mathrm{in} / \mathrm{yr}$ and average $1.7 \mathrm{in} / \mathrm{yr}$.

Discharge from the Antlers aquifer occurs mostly as discharge to streams, upward leakage, and pumpage. Laine and Cummings (1963), in their study of the surface water in the Kiamichi River basin, reported that Gates 
Creek downstream from Fort Towson, Oklahoma, T. 6 S., T. 19 E., had a discharge of 4.1 $\mathrm{ft}^{3} / \mathrm{s}$ on August 14, 1962, when the flow was negligible in many small streams in the upper Kiamichi River basin (plate 1A). On August 14,1962 , the flow in the Kiamichi River near Belzoni, Oklahoma, T. 4 S, R. 18 E., was 5.3 $\mathrm{ft}^{3} / \mathrm{s}$, whereas the flow in the Kiamichi River had increased to $15.7 \mathrm{ft}^{3} / \mathrm{s}$ in the $5 \mathrm{mi}$ downstream from Belzoni to the town of Apple, Oklahoma, T. 5 S, R. 18 E. On July 10, 1942, the discharge at Belzoni was $33 \mathrm{ft}^{3} / \mathrm{s}$ compared to $47.9 \mathrm{ft}^{3} / \mathrm{s}$ near Apple and $10.2 \mathrm{ft}^{3} / \mathrm{s}$ in Gates Creek. The average increase for the 2 measurements between Belzoni and Apple is 12.6 $\mathrm{ft}^{3} / \mathrm{s}$. The increased streamflows occur within the Antlers outcrop thereby indicating that the Antlers is discharging to the stream. Baseflow measurements on the Blue River at Milburn, Oklahoma, T. 3 S., R. 7 E., averaged $33.1 \mathrm{ft}^{3} / \mathrm{s}$ (U.S. Geological Survey, 1966-67, $1978,1980-81$ ), during January of 1965,1966 , 1977,1979 , and 1980 when precipitation was below normal. Approximately $25 \mathrm{mi}$ downstream, base-flow measurements in January during the same years on the Blue River near Blue, Oklahoma, T. 6 S., R. 10 E., averaged $39.3 \mathrm{ft}^{3} / \mathrm{s}$. Although about $14 \mathrm{mi}$ of the streambed is in the younger confining unit overlying the Antlers aquifer and flow is toward the river in the younger confining unit (plate 2B), some of the $6.2 \mathrm{ft}^{3} / \mathrm{s}$ increase in flow in the $25 \mathrm{mi}$ between the two stream gages likely is from the Antlers. Thus, longterm base-flow data for the Blue River indicates that the Antlers aquifer is discharging to the Blue River most of the time.

The table on the next page, modified from Hart and Davis (1981), shows the results of a series of low-flow measurements on four streams widely spaced on the Antlers outcrop (plate 2A). The average base flow in the four streams ranged from 0.8 to $4.3 \mathrm{ft}^{3} / \mathrm{s}$ and the total average base flow was $11 \mathrm{ft}^{3} / \mathrm{s}$.
The range and average base-flow measurements for Little Huauni, Dumpling, Davis, and Gates Creeks (plate 2A) were reported by Hart and Davis (1981) and measurements on the Kiamichi and Blue Rivers were reported by Laine and Cummings (1963). The total base flow for the six streams is about $30 \mathrm{ft}^{3} / \mathrm{s}$, or $21,720 \mathrm{acre}-\mathrm{ft} / \mathrm{yr}$.

In addition to the discharge to streams in . the outcrop area, upward leakage from the Antlers aquifer into the younger confining unit probably accounts for considerable discharge from the Antlers.

Ground-water evapotranspiration from the Antlers is not significant because depth to the water table below land surface generally exceeds $50 \mathrm{ft}$ except along some streams; the area of shallow water table along the principal streams is small.

Discharge from the Antlers aquifer also includes pumping from wells for municipal, irrigation, and industrial use as discussed in the section on ground-water use.

\section{Hydraulic Conductivity, Storage Coefficient, and Specific Yield}

Aquifer hydraulic conductivity values were calculated from transmissivity values determined from 21 aquifer tests and from saturated thicknesses. The aquifer tests were made at five different locations across the study area in the confined part of the aquifer (Hart and Davis, 1981). The hydraulic conductivity values ranged from 0.87 to $3.75 \mathrm{ft} / \mathrm{d}$, and represent average values for the entire section tested.

Vertical hydraulic conductivity data for the younger confining unit are not available. An initial approximation of vertical hydraulic conductivity of the younger confining unit was determined from Freeze and Cherry (1979), who give a range of hydraulic conductivities for different rock types. Based on the general lithologic character of the younger confining 


\begin{tabular}{|c|c|c|c|c|}
\hline Station name & $\begin{array}{l}\text { Location } \\
\text { (township, } \\
\text { range, section }\end{array}$ & $\begin{array}{l}\text { Drainage } \\
\text { area } \\
\text { (square } \\
\text { miles) }\end{array}$ & Date & $\begin{array}{l}\text { Discharge } \\
\text { (cubic } \\
\text { feet } \\
\text { per } \\
\text { second) }\end{array}$ \\
\hline $\begin{array}{l}\text { Little Huauni } \\
\text { Creek near } \\
\text { Lebanon, Okla. }\end{array}$ & 6S-4E-17SWSWSW & 25.0 & $\begin{array}{l}10 / 28 / 75 \\
11 / 17 / 75 \\
12 / 11 / 75 \\
01 / 21 / 76\end{array}$ & $\begin{array}{l}2.7 \\
2.6 \\
3.0 \\
3.3\end{array}$ \\
\hline $\begin{array}{l}\text { Davis Creek at } \\
\text { Caney, Okla. }\end{array}$ & 4S-10E-01SESESW & 14.2 & $\begin{array}{l}10 / 29 / 75 \\
11 / 17 / 75 \\
12 / 11 / 75 \\
01 / 21 / 76\end{array}$ & $\begin{array}{l}0.4 \\
0.6 \\
1.1 \\
1.1\end{array}$ \\
\hline $\begin{array}{l}\text { Dumpling Creek. } \\
\text { near Antlers, Okla. }\end{array}$ & 4S-16E-22SWSESE & 24.2 & $\begin{array}{l}10 / 29 / 75 \\
11 / 18 / 75 \\
12 / 12 / 75 \\
01 / 22 / 76\end{array}$ & $\begin{array}{l}0.7 \\
2.4 \\
4.8 \\
4.2\end{array}$ \\
\hline $\begin{array}{l}\text { Gates Creek near } \\
\text { Fort Towson, Okla. }\end{array}$ & 6S-20E-06NWSENW & 18.9 & $\begin{array}{l}10 / 29 / 75 \\
11 / 18 / 75 \\
12 / 12 / 75 \\
01 / 22 / 76\end{array}$ & $\begin{array}{l}3.5 \\
4.0 \\
5.2 \\
4.7\end{array}$ \\
\hline
\end{tabular}

unit and on the assumption that vertical hydraulic conductivity is usually less than horizontal hydraulic conductivity, the initial estimate was $1.5 \times 10^{-4} \mathrm{ft} / \mathrm{d}$.

An average storage coefficient of 0.0005 for the confined part of the Antlers aquifer was determined from the 21 aquifer tests by Hart and Davis (1981). With unconfined conditions the storage coefficient is almost equal to the specific yield. A specific yield of 0.17 , for the Antlers outcrop area, was estimated from lithologic descriptions of the Antlers in conjunction with specific yield studies of different rock types (Johnson, 1967).

\section{GROUND-WATER USE}

The locations of wells that yield several hundred gallons per minute or more are shown on plate 2C. Most irrigation wells in the study area are in Love County. The locations of irrigation wells, acres irrigated, and the number of times per year each plot was irrigated were obtained from the Oklahoma Water Resources Board. According to irrigators in the area, annual application rates range from 10 to 12 in/acre. Return flow relative to the small quantity of irrigation use is negligible in the study area. Demographic information and well data for populations served by ground water in towns, rural water districts, trailer parks, resorts, and similar public places were obtained from the Environmental Health Ser- 
vices State Water Quality Laboratory, (1979). Average per capita use of ground water in Oklahoma in 1980 was $130 \mathrm{gal} / \mathrm{d}$ according to Solley, Chase, and Mann (1983). Water use by industry was obtained by personal communication. Data for industrial, municipal, and irrigation pumpage in Texas was supplied by Nordstrom (1982).

Hart and Davis (1981) estimated that total pumpage for public supply, irrigation, and industrial use from the Antlers aquifer in Oklahoma was about 5,600 acre- $\mathrm{ft}$ in 1975 . Estimated 1980 pumpage for public supply, irrigation, and industrial uses determined for this study is 4,600 acre-ft for Oklahoma. The difference in the two values probably is attributable to a difference in estimating methods or source data rather than a decrease in pumpage. Large-capacity wells, which account for almost all pumpage from the aquifer in Texas, pumped about 16,100 acre-ft from the Antlers in 1980 (Nordstrom, 1982).

South of the Red River in Texas, pumpage from the Antlers is mostly in Cooke and Grayson Counties. According to Nordstrom (1982) total pumpage from the Antlers from largecapacity wells in Cooke and Grayson Counties was about 7,570 acre-ft in 1976. There is little or no pumpage from the Antlers to the east of Grayson County; instead water is pumped from shallower Cretaceous rocks.

\section{DESCRIPTION OF THE DIGITAL MODEL}

\section{General Discussion}

All digital model simulations used the U.S. Geological Survey modular model developed by McDonald and Harbaugh (1989). The model solves a large system of simultaneous linear equations representing ground-water flow by a finite-difference method. The model simulates the head and flow response of the aquifer and the confining beds to pumpage and natural discharge.

The aquifer was divided into rectangular cells, and average aquifer properties were assigned to each cell. Most of the rectangular cells for the modeled area were regularly dimensioned $2 \mathrm{mi}$ north-south, and 3 mi eastwest across approximately the northern 85 percent of the cell matrix (plate 2C). The cells in the southern part of the matrix were expanded southward so that the ratio of the north-south dimension of an expanded cell to the same dimension of an adjacent cell to the north was no greater than 1.5. The resulting finite-difference grid consisted of 29 rows and 58 columns. Depending on the simulation, appropriate cells then were assigned values for aquifer head, storage coefficient, hydraulic conductivity of the aquifer, base of the aquifer, top of the aquifer, vertical conductance (vertical hydraulic conductivity of the younger confining unit, divided by its thickness, $K^{\prime} / b^{\prime}$ of the younger confining unit, altitude of the water table, and recharge. Boundary conditions were specified at the appropriate nodes as described in the next section. Such data then were used in the model to simulate groundwater flow in the aquifer system. The simulation results are expressed as head changes in the aquifer for each cell and as simulated components of flow summarized in a mass balance.

The saturated thickness of the younger confining unit was calculated by subtracting the altitude of the top of the Antlers from the altitude of the potentiometric surface of the younger confining unit.

The following diagrammatic section illustrates the relation between the geologic units, the hydrogeologic units, and the model units. The section shows one active layer overlain by a simulated confining unit through which vertical leakage passes from a source or sink in the confining unit. Horizontal flow and storage in the confining unit are assumed to be negligible. The vertical leakage is controlled by dif- 


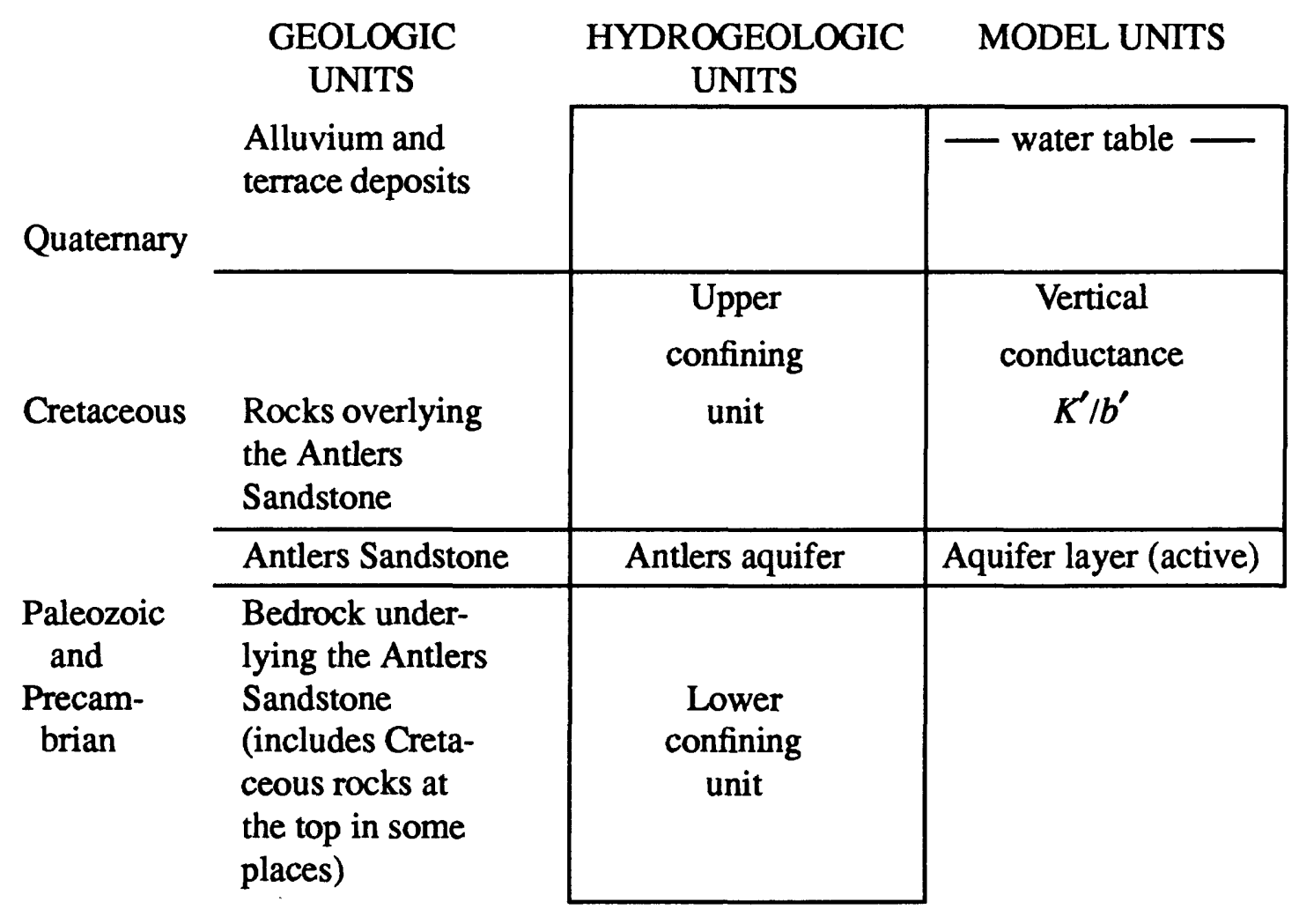

ferences in head between the water table and the aquifer, and the confining-unit vertical conductance.

\section{Model Boundaries}

The locations and types of boundaries used in the model are shown on plate 2C. The no-flow boundary on the west perimeter represents the limit of the Antlers where it has been eroded leaving the underlying, relatively less permeable rocks of Pennsylvanian or Permian age exposed. The no-flow boundary on the north represents the extent of the aquifer where the Antlers has been removed by erosion exposing less permeable rocks of Pennsylvanian age, or older. The no-flow boundary on the east is a flow line at the eastern edge of the study area where ground-water flow is to the south (plate 1A) and therefore, parallel to the boundary as far south as control is available in T. 7 S. The contact between the Antlers and the underlying older rocks was assumed to be a no-flow boundary because the underlying rocks are much less permeable than the aquifer. The water table at the top of the younger confining unit was modeled as a specified-head boundary.

A head-dependent flux boundary was used at the southern edge of the modeled area to represent flow downdip into parts of the aquifer south of the simulated area. With such a boundary, a constant head is assigned at a sufficient distance from the modeled area such that the position of the assigned distant constant head has minimal effect on heads in the modeled area. The head values used for the head-dependent flux boundary were the restored starting heads in the Antlers used in the modeled area for row 29 (plate 2C) as described later in this report. Conductance values for the head-dependent boundary were the product of aquifer hydraulic conductivity, 
cell width, and aquifer thickness, divided by the length of the flow path. The location of the head-dependent flux boundary coincides roughly with the position of the interface between freshwater and brine described more fully in the section on the ground-water flow system.

A constant-head boundary was used for Hugo Lake in Choctaw and Pushmataha Counties, for the northern end of Lake Texoma in Marshall and Johnston Counties, and for that part of Lake Texoma overlying the Antlers outcrop on the Love-Johnston County line.

Larger streams such as the Blue River, Clear Boggy and Muddy Boggy Creeks, and others that traverse the Antlers outcrop are gaining streams most of the year and are modeled as head-dependent flux boundaries in which vertical leakage occurs between the streams and the aquifer proportional to the difference between the stream stage and the aquifer head.

In the confined area, a specified-head boundary representing the water table serves as a source-sink layer. Diffuse leakage between the aquifer and the water table occurs across the intervening confining unit proportional to the difference between the water-table head and the aquifer head.

Cells with pumping wells are simulated as constant-discharge boundaries and are shown on plate $2 \mathrm{C}$. The wells are plotted by location, but all the pumpage in each cell is simulated as if it were distributed over the area of the cell. Cells in the outcrop area constitute a constantrecharge boundary as indicated on plate $2 \mathrm{C}$.

\section{Assumptions and Calibration of the Model}

The digital model used in this study is based on the following assumptions.

1. The geologic materials underlying the aquifer form an impermeable barrier to the flow of water.
2. Streams in the area are in hydraulic connection with the ground-water system downstream from the point at which they become gaining streams.

3. Recharge in the outcrop area is constant with time.

4. Future pumpage of the aquifer is based on available projections of population growth for the study area; and that changes in farming practices, crop demand, and government farm policies will not significantly affect agricultural pumping.

Steady-state calibration without pumpage consisted of adjusting input data within narrow limits until calculated heads closely matched heads measured in 1970 in the Antlers aquifer. The aquifer is considered to be at, or near, steady state most of the time based on the lack of long-term change in ground-water levels. Thus the year selected for calibration was not critical. The values for recharge, aquifer hydraulic conductivity, and hydraulic conductivity of the younger confining unit were adjusted within reasonable limits during the steady-state calibration in order to simulate measured heads and discharge to streams. The final recharge values, adjusted for steady-state calibration, were $0.32 \mathrm{in} / \mathrm{yr}$ in columns $1-41$ to about $0.96 \mathrm{in} / \mathrm{yr}$ in columns $42-58$. The larger recharge rate beginning with column 42 is due to the increase in annual precipitation and the associated increase in recharge from west to east as shown by Pettyjohn, White, and Dunn (1983). Adjusted aquifer hydraulic conductivity values were 5.74 in rows $1-22$ to $0.57 \mathrm{ft} / \mathrm{d}$ in rows 23-29. The reduced aquifer hydraulic conductivity beginning with row 23 is explained by the downdip decrease in sand percentage as shown by Hart and Davis (1981). Adjusted uniform hydraulic conductivity of the confining unit was $2.07 \times 10^{-4} \mathrm{ft} / \mathrm{d}$.

The difference between the recharge values calculated from the base-flow measurements of Hart and Davis (1981) (1.7 in/yr, average) and the adjusted values required to 
calibrate the model $(0.32-0.96 \mathrm{in} / \mathrm{yr})$ is explained as follows: Near tributary streams, some of the precipitation that infiltrates the ground does not become recharge but moves laterally, and shortly reappears in the stream, and later is measured at a downstream point as part of base flow. For a local cycle of this kind to be included in the model simulations would necessitate an impractically small grid size. Therefore ground-water flow models rarely simulate all of the recharge, or stream base flow, when a practical (but larger) grid spacing is used. The recharge rate that is put into a model cell is a net rate that represents the algebraic sum of the actual recharge and discharge within the area represented by the cell; thus, the net recharge rate will be less than the actual recharge rate. In contrast, base-flow measurements on streams include all the recharge collected by streams. Only a small component of recharge that flows downdip is not included in base flow. However, the calculated recharge rate and that resulting from calibration are in reasonable agreement.

Because recharge, aquifer hydraulic conductivity, and the vertical hydraulic conductivity of the younger confining unit were adjusted as described, and because numerous combinations of these properties will produce an acceptable agreement with measured heads, the calibration is not unique.

Streamflow data for streams large enough for modeling were insufficient for comparison with computed leakage values except for the reach of the Blue River near Milburn where four model cells had a combined leakage of $3.87 \mathrm{ft}^{3} / \mathrm{s}$. This leakage value is comparable with the increase of $6.2 \mathrm{ft}^{3} / \mathrm{s}$ between Milburn and Blue reported earlier. The $6.2 \mathrm{ft}^{3} / \mathrm{s}$, however, includes an unknown component of discharge from the younger confining unit.

Comparability of 1970 computed steadystate heads with 1970 observed heads is judged mathematically by using the sum of the absolute values of the difference between measured and computed heads at each cell. This sum is $23,263 \mathrm{ft}$ and the mean is $27.86 \mathrm{ft}$ per cell. Since the contour intervals are known only to 10 or $20 \mathrm{ft}$ on the topographic maps used to calculate the potentiometric surface map, the mean difference per cell of $27.86 \mathrm{ft}$ approximates the limit of accuracy afforded by the head data available for the model. Because the differences between simulated and observed head values are both positive (computed head is lower than the measured head) and negative (computed head is higher than measured head), the mean difference between measured and computed heads, when the sign is used, is $-0.003 \mathrm{ft}$. The maximum difference is $152 \mathrm{ft}$ and minimum difference is $-86 \mathrm{ft}$. All differences between simulated and measured heads are randomly distributed in space.

The instantaneous mass balance or rate of flow shows the hydrologic components of inflow to and outflow from the ground-water system. The algebraic sum of such components should approximate zero; however, rounding errors in the finite-difference equations used in the model prevent perfect massbalance results. The steady-state mass balance for the simulation of 1970 observed heads is shown in table 1 . The large number of significant figures shown are the result of the model's computational procedure, and are not intended to represent the accuracy of flow-rate estimates developed through the modeling process. A diagrammatic sketch illustrating the flow components from the mass balance is shown in figure 3.

Data were not available to prepare a prepumping potentiometric-surface map for calibration purposes because records of groundwater levels are not available for the early part of this century. Therefore, computed steadystate heads from the simulation of 1970 observed heads were used as starting heads in a transient simulation consisting of 60 pumping periods from 1911 to 1970 . Historical pumping data provided by the Oklahoma 
Table 1. Steady-state mass balance for 1970

Cubic feet

per second

Inflow :

$\begin{array}{rc}\text { Storage } & 0.00 \\ \text { Constant head } & 52.22 \\ \text { Recharge } & 59.29 \\ \text { River leakage } & 1.73 \\ \text { Head-dependent boundary } & 0.00092 \\ \text { Total inflow } & 113.25\end{array}$

Outflow:

\begin{tabular}{rc} 
Storage & 0.00 \\
Constant head & 38.53 \\
Recharge & 0.00 \\
River leakage & 74.71 \\
Head-dependent boundary & 0.00 \\
Total outflow & 113.24 \\
Inflow - Outflow & 0.012 \\
Percent difference & -0.01 \\
\hline
\end{tabular}

Water Resources Board and by Nordstrom (1982) beginning in 1911 were used in the transient simulation. Simulation results showed that on average the computed water level was about $2 \mathrm{ft}$ lower than the observed water level for 1970 . Since the recharge rate is the least well-known model parameter, recharge was progressively increased a total of about 10 percent in a series of simulations until the average difference between $1970 \mathrm{com}$ puted and observed heads was a 2 -ft net waterlevel rise. The recharge was applied uniformly to the earlier recharge rates whose distribution was described in the section on calibration of the model. The computed heads simulated with the increased recharge then were used as starting heads in a second transient simulation from 1911 to 1970 . The difference between the average computed heads and the average 1970 observed heads from the second transient simulation was zero. The head values from the second transient simulation then were used as starting heads in all subsequent projected simulations. In the procedure described above, a storage coefficient of 0.17 was specified for the unconfined part of the aquifer and 0.0005 was specified for the confined part. The 1970 mass balance is shown in table 2 .

One of the ways to judge the accuracy of a map derived from computed data generated by a digital model simulation is to compare it to a corresponding map made from observed data. The computed potentiometric surface map shown on plate $3 \mathrm{~A}$, derived from the 1970 steady-state simulations, compares favorably with the observed potentiometric surface shown on plate $1 \mathrm{~A}$ except in the southeast part

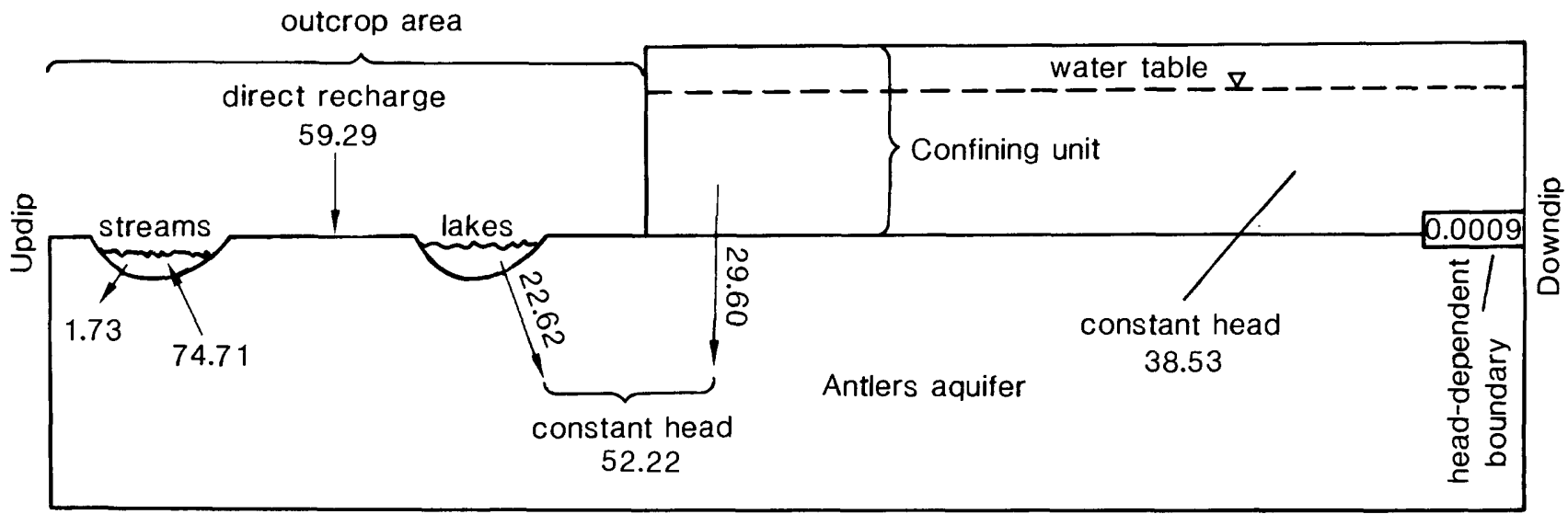

Flow components in cubic feet per second

Figure 3. Diagrammatic sketch showing flow components from the steady-state mass balance. 
Table 2. Mass balance for transient simulation (1911-70)

Cubic feet

per second

Inflow :

$\begin{array}{rr}\text { Storage } & 6.01 \\ \text { Constant head } & 59.33 \\ \text { Wells } & 0.00 \\ \text { Recharge } & 65.31 \\ \text { River leakage } & 1.70 \\ \text { Head-dependent boundary } & 2.97 \\ \text { Total inflow } & 135.32\end{array}$

Outflow:

\begin{tabular}{rc} 
Storage & 0.66 \\
Constant head & 36.31 \\
Wells & 20.87 \\
Recharge & 0.00 \\
River leakage & 78.31 \\
Head-dependent boundary & 0.036 \\
Total outflow & 135.59 \\
Inflow - Outflow & -0.27 \\
Percent difference & 0.20 \\
\hline
\end{tabular}

of the study area where an eastward flow direction is shown on plate $3 \mathrm{~A}$. The model should be considered less re 1 listic in the southeast part of the area because of the scarcity of well control. The cone of depression near Sherman, Texas, is deeper on plate $3 \mathrm{~A}$ than on plate $1 \mathrm{~A}$ possibly because of lack of additional well control for the observed map.

Calibration under transient conditions was not possible because historical pumpage in the Antlers has been insufficient to cause a large enough change of heads to allow transient calibration for a given time period. Consequently, the projected head changes simulated in this study are estimated with a model that is uncalibrated and unverified against transient pumping stress.

\section{Sensitivity Analysis}

Because recharge, aquifer hydraulic conductivity, and vertical conductivity of the younger confining unit were adjusted during steady-state calibration, a sensitivity analysis was made to determine which of the three stated parameters have the greatest and least control on the flow system.

Figure 4 shows the sensitivity or rate of change in the mean of the difference between computed and measured heads when recharge, aquifer conductivity, and vertical conductivity of the confining layer are increased and decreased by 10 percent. The slopes of the lines in figure 4 show that the greatest response is to changes in aquifer hydraulic conductivity and the least response is to changes in vertical hydraulic conductivity of the confining layer.

\section{PUMPING SIMULATIONS FOR DECENNIAL YEARS, 1990-2040}

Well locations and projected pumping rates for wells (table 3 ) in Oklahoma through 2040 were supplied by the staff of the Oklahoma Water Resources Board. Well locations and 1980 pumping rates in Texas were furnished by Nordstrom (1982), and projected pumping rates for wells in Texas through 2030 are based on data given in Freeze and Nichols, Inc. (1980), and used as requested by the cooperator, the U.S. Army Corps of Engineers. The rates for 2040 were determined by linear extrapolation of the antecedent pumping rates. Projected model simulations are for decennial years from 1990 to 2040. Results of the projected simulations are shown on plates $3 B$ to 7C. All projected simulations are transient, and computed heads from one pumping period were used as initial heads for the next pumping period.

Most stress to the Antlers aquifer is the result of pumping municipal, industrial, and irrigation wells. Listed in table 3 are the 1980 pumping rates for grid cells with more than 35 


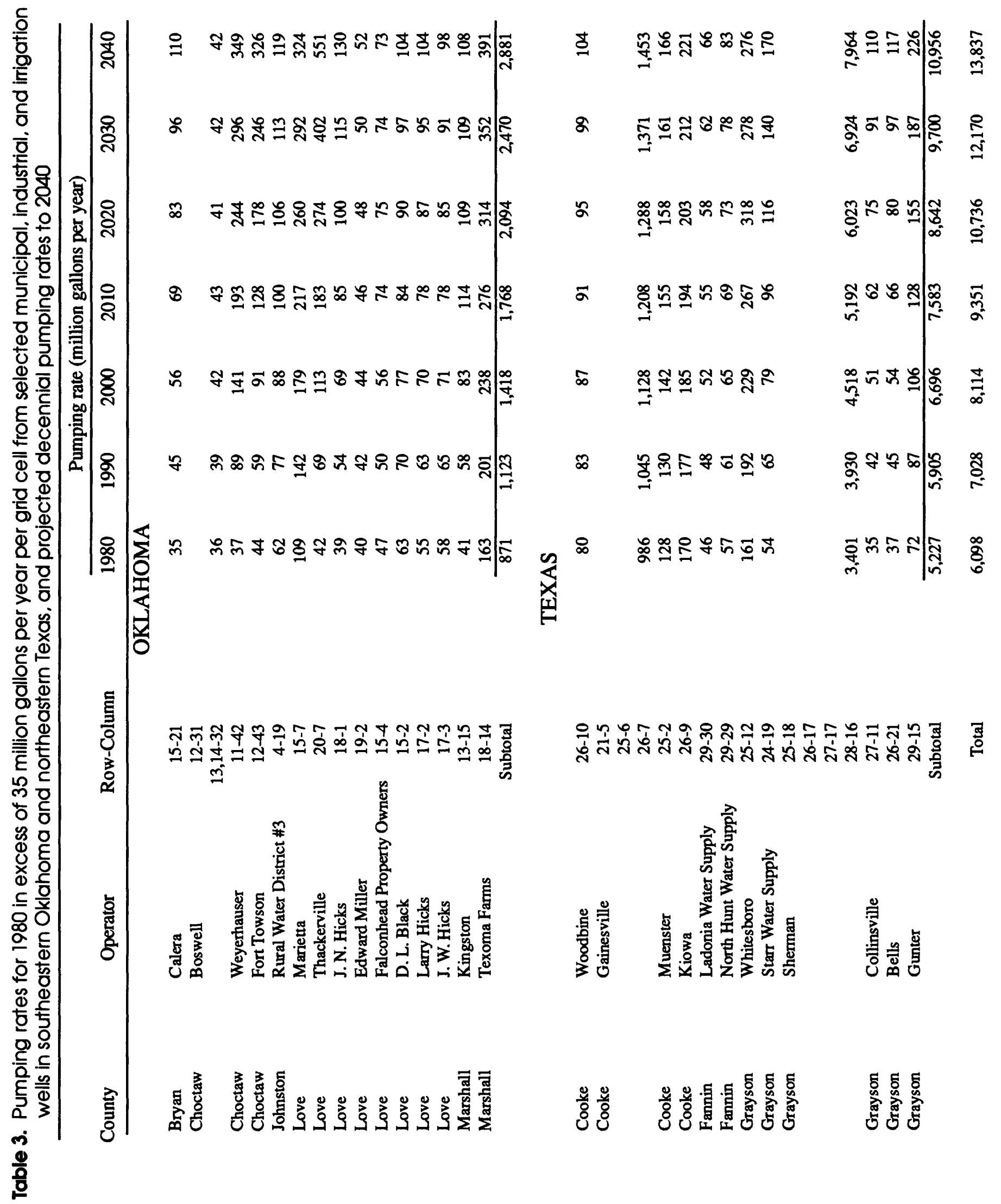




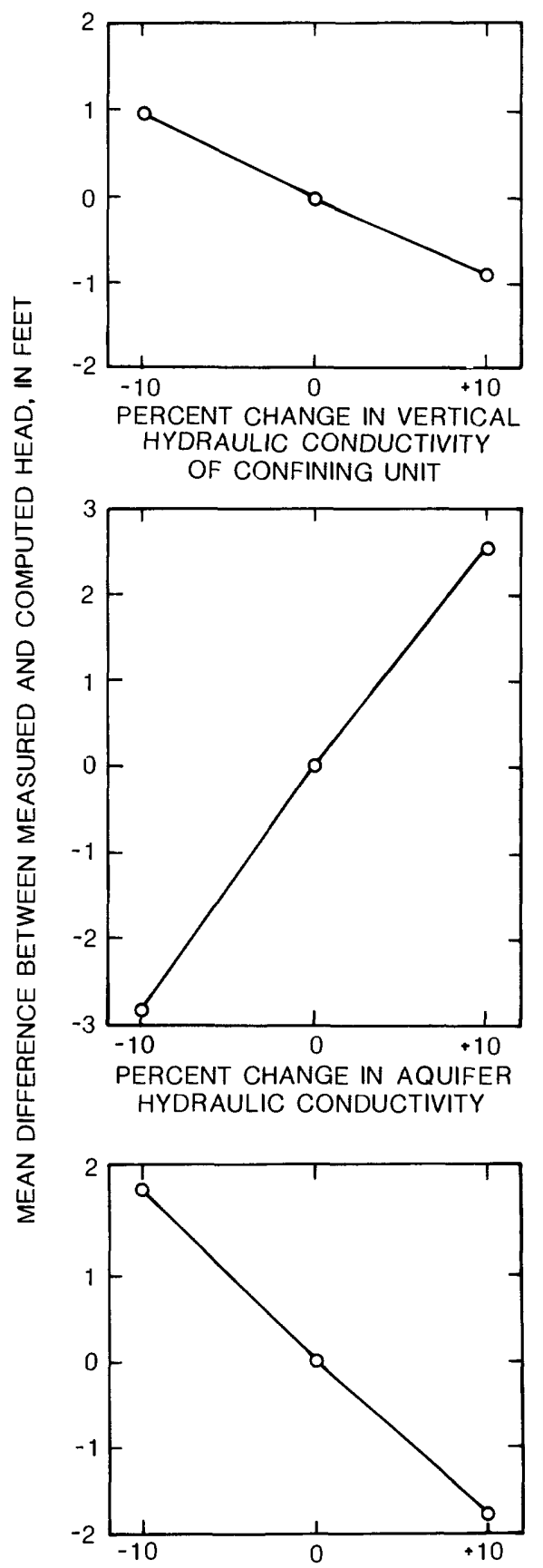

PERCENT CHANGE IN RECHARGE RATE

Figure 4. Graphs showing sensitivity to change in hydraulic conductivity of confining unit, aquifer hydraulic conductivity, and recharge rate during steady-state simulation of 1970 head distribution.
$\mathrm{Mgal} / \mathrm{yr}$ pumped from selected municipal, industrial, and irrigation wells, and projected pumping rates for each decennial year from 1990 through 2040. The value of $35 \mathrm{Mgal} / \mathrm{yr}$ was chosen so that the three types of wells are represented, and also to identify the major pumping centers.

Plates 3B through 5A show that few, if any, changes occur in the potentiometric surface except at the two major pumping centers near Sherman and Gainesville, Texas, where a decline in the potentiometric surface over the years is apparent. Near Sherman, Texas, the altitude of the potentiometric surface is lowered to more than $800 \mathrm{ft}$ below sea level by 2040; however, confined aquifer conditions continue.

Plates 5B through 7A, the drawdown maps, show the progressive expansion of the cone of depression surrounding the principal pumping centers near Sherman and Gainesville, Texas. A projected drawdown of slightly more than $700 \mathrm{ft}$ by 2040 is shown near Sherman, Texas. Table 4 shows the mass balance at the end of the 2040 projected simulation.

Plate 7B shows the projected saturated thickness of the Antlers aquifer by 2040 . Because pumping in the unconfined part of the aquifer is minimal, the maximum decrease by 2040 is less than $10 \mathrm{ft}$ and is less than $1 \mathrm{ft}$ over most of the unconfined area.

Few data are available on yields from properly engineered, fully penetrating, screened water wells for the preparation of a potential well yield map. To assure a conservative estimate of well yield, half of the available drawdown was used. A reasonable representation of potential well yield (plate 7C) was computed by dividing the interval between the potentiometric surface and the base of the aquifer by two and multiplying the result by the average specific capacity of 6.78 (gal/min)/ft, Hart and Davis (1981). The average specific capacity was determined from 21 aquifer tests located in five places across the 
Table 4. Mass balance at end of projected simulation to 2040

\begin{tabular}{lrr}
\hline & & $\begin{array}{c}\text { Cubic f } \\
\text { per secon }\end{array}$ \\
& & \\
Inflow : & Storage & 20.42 \\
& Constant head & 81.94 \\
Wells & 0.00 \\
& Recharge & 65.30 \\
River leakage & 1.74 \\
Head-dependent boundary & 1.37 \\
Total inflow & 170.77
\end{tabular}

Outflow:

$\begin{array}{rc}\text { Storage } & 0.00035 \\ \text { Constant head } & 28.40 \\ \text { Wells } & 69.07 \\ \text { Recharge } & 0.00 \\ \text { River leakage } & 73.33 \\ \text { Head-dependent boundary } & 0.00 \\ \text { Total outflow } & 170.80 \\ \text { Inflow - Outflow } & -0.028\end{array}$

study area. On plate $7 \mathrm{C}$ a $100-\mathrm{gal} / \mathrm{min}$ contour interval shows no change in potential well yield to 2040, and a smaller contour interval is untenable. Therefore, drawdown in the outcrop area is so small that the well yields are expected to be unchanged during the simulation period. In the confined area, well yields will decrease when the potentiometric surface falls below the base of the younger confining unit, but the Antlers aquifer is so thick that well yield can be maintained by deeper drilling.

The calculated amount of water in storage in 1970 was $916,556,000$ acre-ft. The volumetric results of the six projections are shown below.

The rapid decrease in storage from the time simulated pumping began (1970) to the first projection year (1990) followed by a marked slowing of the rate of storage decrease is typical of a confined aquifer. Pumping induces vertical leakage through the confining layer. The water thus transmitted recharges the aquifer, thereby slowing the initial rate of storage loss and moderating the loss through time.

The water volumes remaining in storage for 1970 and the projection years are calculated for the unconfined part of the modeled area, and may include slightly saline water in the southeast part. Because of the elasticity of the aquifer and the very slight compressibility of water, a small additional volume of water would be recovered from the confined part of the aquifer as water levels are lowered to pro-

\begin{tabular}{ccccc}
\hline & $\begin{array}{c}\text { Water } \\
\text { pumped } \\
\text { since 1970 } \\
\text { (acre-ft) }\end{array}$ & $\begin{array}{c}\text { Water } \\
\text { remaining } \\
\text { in storage } \\
\text { (acre-ft) }\end{array}$ & $\begin{array}{c}\text { Decrease } \\
\text { in } \\
\text { storage } \\
\text { since 1970 } \\
\text { (acre-ft) }\end{array}$ & $\begin{array}{c}\text { Decrease } \\
\text { in } \\
\text { storage } \\
\text { since 1970 } \\
\text { (percent) }\end{array}$ \\
\hline 1990 & 733,000 & $916,441,000$ & 115,000 & 0.012 \\
2000 & $1,020,000$ & $916,389,000$ & 167,000 & 0.018 \\
2010 & $1,352,000$ & $916,326,000$ & 230,000 & 0.025 \\
2020 & $1,735,000$ & $916,241,000$ & 315,000 & 0.034 \\
2030 & $2,180,000$ & $916,126,000$ & 430,000 & 0.047 \\
2040 & $2,680,000$ & $915,988,000$ & 568,000 & 0.062 \\
\hline
\end{tabular}


duce unconfined conditions. Based on the relative storage values for unconfined and confined conditions, the additional volume probably is less than 0.3 percent. If the potentiometric surface in the confined part of the aquifer declines to unconfined conditions as the result of increased pumping, not all the water in storage may be economically recoverable because of increased lifting costs, especially in the downdip part of the modeled area.

\section{SUMMARY AND CONCLUSIONS}

The Antlers Sandstone of Early Cretaceous age occurs in all or parts of Atoka, Bryan, Carter, Choctaw, Johnston, Love, Marshall, McCurtain, and Pushmataha Counties, a 4,400-square-mile area in southeastern Oklahoma parallel to the Red River. The sandstone comprising the Antlers aquifer is exposed in the northern one-third of the area, and ground water in the outcrop area is unconfined. Younger Cretaceous rocks overlie the Antlers in the southern two-thirds of the study area where the aquifer is confined. The Antlers extends in the subsurface south into Texas where it underlies all or parts of Bowie, Cooke, Fannin, Grayson, Lamar, and Red River Counties. An area of approximately 5,400 square miles in Texas is included in the study.

The Antlers Sandstone consists of sand, clay, conglomerate, and limestone deposited on an erosional surface of Paleozoic rocks. Saturated thickness in the Antlers ranges from 0 feet at the updip limit to probably more than 2,000 feet, 25 to 30 miles south of the Red River.

Simulated recharge to the Antlers based on model calibration ranges from 0.32 to about 0.96 inch per year. Base flow increases where streams cross the Antlers outcrop, indicating that the aquifer supplies much of the base flow.

Pumpage rates for 1980 in excess of 35 million gallons per year per grid cell for public supply, irrigation, and industrial uses total 872 million gallons in the Oklahoma part of the Antlers and 5,228 million gallons in the Texas part of the Antlers.

Ground-water flow in the Antlers aquifer was simulated using one active layer in a three-dimensional finite-difference mathematical model. Simulated aquifer hydraulic conductivity values range from 0.87 to 3.75 feet per day. A vertical hydraulic conductivity of $1.5 \times 10^{-4}$ foot per day was specified for the younger confining unit in the simulation. An average storage coefficient of 0.0005 was specified for the confined part of the aquifer; a specific yield of 0.17 was specified for the unconfined part.

Because pumping from the Antlers is minimal, calibration under transient conditions was not possible. Consequently, the head changes resulting from projection simulations in this study are estimates only. Ground-water hydrologic data described in the report indicates that steady-state conditions exist throughout most of the Antlers aquifer. This interpretation is supported by the results of the model simulations. Volumetric results of the six projection simulations from the years 1990 to 2040 , usually at steadily increasing pumping rates, indicate that the decrease in the volume of ground water in storage due to pumping approximately $9,700,000$ acre-feet from 1970 to 2040 is less than 0.1 percent. Therefore, if future pumping rates do not significantly exceed the pumping rates used in the six projections, the quantity of water in the Antlers aquifer should be virtually unchanged except near the outcrop limits where saturated thickness becomes very thin.

\section{SELECTED REFERENCES}

Davis, L.V., 1960, Geology and ground-water resources of southern McCurtain County, Oklahoma: Oklahoma Geological Survey Bulletin 86, 108 p.

Davis, R.E., and Hart, D.L., Jr., 1978, Hydrologic data for the Antlers aquifer, south- 
eastern Oklahoma: U.S. Geological Survey Open-File Report 78-1038, 24 p.

Environmental Health Services State Water Quality Laboratory, 1979, Public water supplies for the State of Oklahoma, southeast district: Oklahoma City, Oklahoma State Department of Health, $108 \mathrm{p}$.

Fay, R.O., 1974, Unpublished reconnaissance mapping (for Oklahoma Geological Survey) in Hart, D.L., Jr., 1974, and Marcher, M.V., and Bergman, D.L., 1983.

Fenneman, N.M., and Johnson, D.W., 1946, Physical divisions of the United States: U.S. Geological Survey, 1 sheet, scale 1:7,000,000.

Frederickson, E.A., Redman, R.H., and Westheimer, J.M., 1965, Geology and petroleum of Love County, Oklahoma: Oklahoma Geological Survey Circular 63, $91 \mathrm{p}$.

Freeze, R.A., and Cherry, J.A., 1979, Groundwater: Englewood Cliffs, N.J., PrenticeHall, Inc., 604 p.

Freeze and Nichols, Inc., 1980, Water usage and supply in the Texas areas of the Red River chloride control study; Checkpoint I report: Tulsa, Okla., U.S. Army Corps of Engineers, $417 \mathrm{p}$.

Hart, D.L., Jr., 1974, Reconnaissance of the water resources of the Ardmore and Sherman quadrangles, southern Oklahoma: Oklahoma Geological Survey Hydrologic Atlas HA-3, 4 sheets, scale 1:250,000.

Hart, D.L., Jr., and Davis, R.E., 1981, Geohydrology of the Antlers aquifer (Cretaceous), southeastern Oklahoma: Oklahoma Geological Survey Circular 81, $33 \mathrm{p}$.

Havens, J.S., and Bergman, D.L., 1976, Ground-water records for southeastern Oklahoma, Part 1-Records of wells and springs: U.S. Geological Survey OpenFile Report 76-889, 59 p.
Huffman, G.G., Alfonsi, P.P., Dalton, R.C., Duarte-Vivas, Andres, and Jeffries, E.L., 1975, Geology and mineral resources of Choctaw County, Oklahoma: Oklahoma Geological Survey Bulletin 120, 39 p.

Huffman, G.G., Hart, T.A., Olson, L.J., Currier, J.D., and Ganser, R.W., 1978, Geology and mineral resources of Bryan County, Oklahoma: Oklahoma Geological Survey Bulletin 126, 113 p.

Johnson, A.I., 1967, Specific yield-Compilation of specific yields for various materials: U.S. Geological Survey WaterSupply Paper 1662-D, 74 p.

Laine, L.L., 1963, Surface water of Kiamichi River basin in southeastern Oklahoma, with a section on Quality of water, by T.R. Cummings: U.S. Geological Survey open-file report, $39 \mathrm{p}$.

Marcher, M.V., and Bergman, D.L., 1983, Reconnaissance of the water resources of the McAlester and Texarkana Quadrangles, southeastern Oklahoma: Oklahoma Geological Survey Hydrologic Atlas HA9, 4 sheets, scale 1:250,000.

McDonald, M.G., and Harbaugh, A.W., 1989, A modular three-dimensional finite-difference ground-water flow model:

U.S. Geological Survey Techniques of Water-Resources Investigations, Book 6, Chapter A1, $586 \mathrm{p}$.

Nordstrom, P.L., 1982, Occurrence, availability, and chemical quality of ground water in Cretaceous aquifers of North Central Texas: Texas Department of Water Resources Report 269, v. 1, 61 p.; v. 2, $386 \mathrm{p}$.

Oklahoma Water Resources Board, 1985, as amended, Rules, regulations, and modes of procedure: Oklahoma Water Resources Board Publication 126, 118 p.

Pettyjohn, W.A., White, Hal, and Dunn, Shari, 1983, Water atlas of Oklahoma: Stillwater, 
Okla., University Center for Water

Research, Oklahoma State University, $72 \mathrm{p}$.

Solley, W.B., Chase, E.B., and Mann, W.B., IV, 1983, Estimated use of water in the United States in 1980: U.S. Geological Survey Circular 1001, 56 p.

U.S. Department of Agriculture, 1966, Soil survey of Love County, Oklahoma: Soil Conservation Service, 94 p.

1974, Soil survey of McCurtain County, Oklahoma: Soil Conservation Service, $99 \mathrm{p}$.

1977, Soil survey of Johnston County, Oklahoma: Soil Conservation Service, $57 \mathrm{p}$.

1978, Soil survey of Bryan County, Oklahoma: Soil Conservation Service, $110 \mathrm{p}$.

1979a, Soil survey of Atoka County, Oklahoma: Soil Conservation Service, $85 \mathrm{p}$.

1979b, Soil survey of Carter County, Oklahoma: Soil Conservation Service, $67 \mathrm{p}$.

1979c, Soil survey of Choctaw County, Oklahoma: Soil Conservation Service, $87 \mathrm{p}$.

1979d, Soil survey of Pushmataha County, Oklahoma: Soil Conservation Service, $75 \mathrm{p}$.

1980, Soil survey of Marshall County, Oklahoma: Soil Conservation Service, $59 \mathrm{p}$.

U.S. Department of Commerce, 1973, Climatography of the United States no. 81 (Oklahoma), Monthly normals of temperature, precipitation, and heating and cooling degree days 1941-70: Asheville, N.C., National Oceanic and Atmospheric Administration, Environmental Data Service, $10 \mathrm{p}$.
U.S. Geological Survey, 1966-67, Waterresources data for Oklahoma, 1965-66, Part 1-Surface-water records: U.S. Geological Survey Water-Data Report (published annually).

1978, Water-resources data for Oklahoma, water year 1977-volume 2: U.S. Geological Survey Water-Data Reports OK-77-2 (published annually).

1980-81, Water-resources data for Oklahoma, water years 1979-80 - volume 2: U.S. Geological Survey WaterData Reports OK-79-2 to OK-80-2 (published annually).

Wayland, J.R., and Ham, W.E., 1955, General and economic geology of the Baum Limestone, Ravia-Mannsville area, Oklahoma: Oklahoma Geological Survey Circular 33, $44 \mathrm{p}$.

\section{GLOSSARY OF TECHNICAL TERMS}

Acre-foot.-The volume of water required to cover one acre to a depth of one foot; equivalent to 43,560 cubic feet or 325,851 U.S. gallons.

Aquifer-A formation, group of formations, or part of a formation that contains sufficient saturated permeable material to yield significant quantities of water to wells and springs.

Base flow.-Sustained or fair-weather runoff usually composed mostly of ground-water discharge.

Comanchean.-North American provincial series: Lower and Upper Cretaceous (above Coahuilan, below Gulfian).

Confined ground water.-Ground water under pressure significantly greater than atmospheric, the upper limit of confined ground water is the bottom of a bed of distinctly smaller hydraulic conductivity than that of the material in which the confined water occurs. 
Conglomerate.-A coarse-grained, clastic sedimentary rock composed of rounded to subangular fragments larger than 2 millimeters in diameter set in a fine-grained matrix of sand, silt, or any of the common natural cementing materials.

Cretaceous.-The final period of the Mesozoic Era thought to have covered the span of time between 138 and 63 million years ago; also, the corresponding system of rocks.

Darcy's law.-An equation expressing laminar flow of fluids through permeable material in which inertia is neglected. In the case of water, flow can be expressed as: $Q=$ $K I A$ in which $Q$ is the discharge, $I$ is the hydraulic gradient, $A$ is the cross-sectional area at right angles to flow, and $K$ is a constant whose value depends on the kind of permeable material and the viscosity of the water.

Evapotranspiration.-Loss of water from a land area through transpiration by plants and evaporation from the soil. Also the volume of water lost through evapotranspiration.

Gaining stream.-A stream or reach of a stream whose flow is being increased by inflow of ground water.

Gulfian.-North American provincial series: Upper Cretaceous (above Comanchean, below Paleocene of Tertiary)

Gradient.-The rate of increase or decrease of a quantity; the slope or grade.

Head, static.-The height above a standard datum of the surface of a column of water (or other liquid) that can be supported by the static pressure at a given point.

Homogeneity.-Synonymous with uniformity. A material is homogeneous if its hydrologic properties are identical everywhere.
Hydraulic conductivity.-If a porous medium is isotropic and the fluid is homogenous, the hydraulic conductivity of the medium is the volume of water at the existing kinematic viscosity that will move in unit time under a unit hydraulic gradient through a unit area measured at right angles to the direction of flow.

Isotropic.-A medium whose physical properties are the same in all directions.

National geodetic vertical datum of 1929.-A geodetic datum derived from a general adjustment of the first-order level nets of both the United States and Canada, formerly called Mean Sea Level.

Paleozoic.-An era of geologic time, from the end of the Precambrian to the beginning of the Mesozoic, from about 570 to about 240 million years ago.

Pennsylvanian.-A period of the Paleozoic Era, and its corresponding system of rocks, thought to have covered the span of time between 330 and 290 million years ago.

Permian.-The last period of the Paleozoic Era, and its corresponding system of rocks, thought to have covered the span of time between 290 and 240 million years ago.

Potentiometric surface.-A surface that represents the static head. As related to an aquifer, the potentiometric surface is defined by the levels to which water will rise in tightly cased wells. The water table is a particular potentiometric surface.

Recharge.-The process involved in the absorption and addition of water to the zone of saturation. Also, the amount of water added.

Return flow.-Irrigation water not consumed by evapotranspiration but returned to its source or to another body of ground or surface water. 
Saturated thickness.-The thickness of the zone below the water table in which all interstices are filled with ground water.

Specific yield.-The ratio of (1) the volume of water that the rock or soil, after being saturated, will yield by gravity to (2) the volume of the rock or soil. The definition implies that gravity drainage is complete.

Steady-state. - In steady-state flow, as of ground water through a permeable material, there is no change in head with time.

Storage coefficient.-The volume of water an aquifer releases from or takes into storage per unit surface area of the aquifer per unit change in head.

Stratigraphy.-The branch of geology that deals with the definition and description of major and minor natural divisions of rocks in outcrop or from the subsurface, and with the interpretation of the significance of such divisions.

Transgressive.-Sediments deposited during the advance or encroachment of water over a land area or during the subsidence of the land, and characterized by an onlap arrangement.

Transient simulation.-A model simulation in which heads in the aquifer and in the confining beds, in the case of a confined aquifer with leakey confining beds, vary with time.

Transmissivity.-The rate at which water of the prevailing kinematic viscosity is transmitted through a unit width of the aquifer under a unit hydraulic gradient.

Unconfined water.-Ground water in an aquifer that has a water table.

Water table.-The water surface in an unconfined water body at which the pressure is atmospheric. The water table is defined by levels at which water stands in wells that penetrate the water body just far enough to hold standing water. In wells that penetrate to greater depths, the water level will stand above or below the water table if an upward or downward component of ground-water flow exists. 